\title{
Job satisfaction and job commitment of Greek tennis, table-tennis and badminton coaches
}

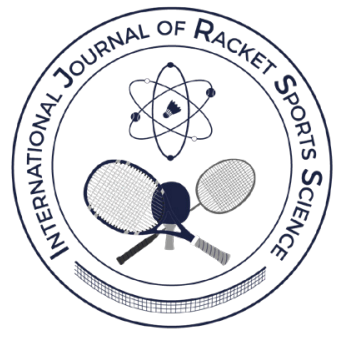

Argiris Theodosiou ${ }^{(1)}$; Amalia Drakou ${ }^{(1)}$; Thomas Sdoukos

Aristotle University of Thessaloniki, School of Physical Education \& Sport Science, Thessaloniki, Greece

Received: 13-07-2020

Accepted: 18-12-2020

\begin{abstract}
The aim of the study was to investigate job satisfaction and job commitment of coaches of the three major racket sports in Greece: tennis, table-tennis and badminton. One hundred and ten $(N=110)$ tennis $\left(N_{T}=61\right)$, table-tennis $\left(N_{T T}=31\right)$ and badminton $\left(N_{B}=18\right)$ coaches responded to the Coach Satisfaction Questionnaire (CSQ), an eleven-factor instrument which assesses coaches' job satisfaction and to the Occupational-Organizational Commitment Scale, a six factor questionnaire which evaluates the different forms of occupational and organizational commitment. Forty six of the coaches were full-time $\left(N_{F T}=46\right)$ whereas of the rest, sixty four were part-time $\left(N_{P T}=64\right)$. The results of a series of t-tests, ANOVAs and correlation analyses revealed various significant differences and relationships. Some of the most important are that: a) tennis coaches and full-time coaches were more satisfied in most of the job satisfaction dimensions, b) significant correlations were noticed between "job satisfaction" and "organizational commitment" variables, c) "autonomy", was a predictor of "organizational affective commitment", d) "satisfaction with coaching job" was the unique predictor of occupational affective and "occupational normative commitment" and e) "team performance" was the only predictor of "occupational continuance commitment". Most of the results are in accordance with the existing job satisfaction literature however, further research is needed on human relation practices of National Federations and/or sport clubs associated with them, in order to have a better understanding of how certain practices and policies lead to higher levels of job satisfaction, organizational and occupational commitment among racket sport coaches.
\end{abstract}

Keywords: Job satisfaction, job commitment, racket sports.

Correspondence author: Argiris Theodosiou, argtheodosiou@phed.auth.gr

\section{Cite this article as:}

Theodosiou, A., Drakou, A., Sdoukos, T. (2020). Job satisfaction and job commitment of Greek tennis, table-tennis and badminton coaches. International Journal of Racket Sports Science, 2(2), 47-58.

This is an open access article under the CC BY license (https://creativecommons.org/licenses/by/4.0/). 


\section{INTRODUCTION}

Job satisfaction is one of the most researched concepts in the field of organizational psychology and it is connected to many and diverse psychological and organizational issues such as burnout, turnover, absenteeism, life satisfaction, job design, performance, emotional labour, leadership, organizational commitment and occupational commitment. From early (Gillet \& Schuwab, 1975; Herzberg, Mausner, \& Snyderman, 1959) to the most recent research (Abuhashesh, Al-Dmour, \& Masa'deh, 2019), the connection between job satisfaction to performance and productivity adds value to the concept, offering practitioners a useful tool for understanding and improving organizational environment, targeting organizational success.

Researchers seem to agree on the multidimensionality of job satisfaction (Courtney \& Younkyoung, 2017; Robbins \& Judge, 2018; Spector, 1997). Pay, colleagues, advancement, working conditions, social recognition, supervision, nature of the job, job autonomy and job security are the most frequently researched dimensions of job satisfaction. Lately, corporate social responsibility has been proved to influence job satisfaction (Robbins \& Judge, 2018).

Job satisfaction is usually studied together with other job attitudes such as job engagement, organizational commitment, perceived organizational support and/or together with the resulting behaviors of job satisfaction (absenteeism, "goldbricking" someone being at the working place but doing less work than he/she is able to, performance, withdrawal). Job satisfaction has also been found to lead to certain positive results such as high job performance (Schleicher et al., 2015), customer satisfaction (Hoseong \& Beomjoon, 2012), life satisfaction (Drakou, Kambitsis, Charachousou, \& Tzetzis, 2006) and organizational citizenship behavior (Podsakoff, Podsakoff, \& McKenzie, 2014).

Another highly researched job attitude is organizational commitment (Erdheim, Wang, \& Zickar, 2006; Grobler \& Govender, 2017). It depicts the total participation of an employee in all organization's activities and it includes the extensions of the efforts that the employee puts in these activities. The fact that total commitment contributes in organizational success makes organizational commitment an area of interest for practitioners too (Chelladurai, 1999). Organizational commitment is generally defined as the degree to which an employee is loyal to his/her organization (Nath Gangai \& Agrawal, 2014). Meyer and Allen (1991) conceptualized a three component model of organizational commitment which includes affective, normative and continuance commitment. Affective commitment refers to an employee's "emotional attachment to, identification with, and involvement in an organization" (Meyer \& Allen, 1991, p. 67). It represents an employee's positive emotional reaction to the organization (Watson \&
Clark, 1997). Normative commitment represents an employee's feelings of obligation to remain in his/her organization. Finally, continuance commitment is the attitude an employee adapts from his/her perceptions of employment alternatives. Precisely, employees who believe they have several viable alternatives will have lower continuance commitment than those who believe they have few alternatives (Meyer \& Allen, 1997). "Continuance commitment reflects high perceived costs of quitting" (Snape, Wing-Hung Lo, \& Redman, 2008, p. 5). These costs can be either work or non-work related (Erdheim et al., 2006).

Occupational commitment is another important job attitude and it becomes more important especially if employees transpose their commitment towards their occupations, whereas careers built in a single organization become rare and more uncertain (Lee, Carswell, \& Allen, 2000). According to Lee and his colleagues (2000) it is defined as a psychological link between a person and his/her occupation that is based on an affective response to the occupation. Barnhill and colleagues (2018) argue that occupational commitment is an extension of organizational commitment since it shares the same three component multidimensionality of organizational commitment mentioned above. Existing research findings revealed positive relationships between elements of the two types of commitment. In particular, Yousaf, Sanders, and Abbas, (2015) using a sample university employees noticed that organizational and occupational affective commitment were positively related to each other. Speaking of sport coaches, affective occupational commitment would characterize one's strong desire to remain in the profession of coaching because it is something the individual wants for various reasons (sport enjoyment, personal investment, enjoying mentoring, etc.). Normative occupational commitment represents the feeling that one ought to remain a sport coach because he/she owes to the profession. Finally, continuance occupational commitment is the recognition of costs associated with quitting coaching (late entering to another profession, lack of community recognition and lack of competitiveness that sport originally has).

\section{Job satisfaction and Commitments}

A lot of research has stabilized the opinion that job satisfaction and organizational/occupational commitment correlate to each other (Iverson, 1992; Lincoln \& Kalleberg, 1990; Mueller, Boyer, Price, \& Iverson, 1994; Srivastava, 2013; Wallace, 1995). However, longitudinal investigations which attempted to determine whether one can be the cause of the other, do not provide significant and solid results.

Many researchers came to the conclusion that there is a significant relationship between job satisfaction and organizational commitment (Ahmad, Ahmad \& Shah, 2010; Mokoena \& Dhurup, 2019; Suma \& Lesha, 2013; Vandenbeghere, 2008). Similarly, job satisfaction 
and occupational commitment seem to be related by a statistically significant positive correlation (Wang, Tao, Ellenbecker, \& Liu, 2011). They are both considered as major predictors of the intention to continue in a profession (Satoh, Watanabe, \& Asakura, 2016).

Traditionally, literature assumes that satisfaction causes commitment (Lincoln \& Kalleberg, 1990; Mueller, et al., 1994; Wallace, 1995). According to the Causal Model of Currivan (1999), job satisfaction together with individual characteristics shapes a certain level of organizational commitment, which, in turn, has an impact on intent to stay. On the other hand, some studies have found that commitment precedes satisfaction (Bateman \& Strasser, 1984; Vandenberg \& Lance, 1992) while other studies have concluded a reciprocal relationship between the two concepts (Lance, 1991; Lincoln \& Kalleberg, 1990; Mathieu, 1991).

\section{Job satisfaction and commitments in sporting environment - relevant studies}

Many studies have investigated job satisfaction of sport coaches (Chelladurai \& Ogasawara, 2003; Drakou, 2006; Mokoena \& Dhurup, 2019) or sport administrative personnel (Bradford Conant, 2017; Fiúekçioglu \& Savaú Duman, 2010; Rintaugu, 2013). In particular, Drakou, Charachousou, Kambitsis, and Tzetzis (2008) investigated sport coaches' satisfaction in Greece among coaches of 11 different sports, using the Coach Satisfaction Scale (CSS) (Drakou, 2006) which explores nine dimensions of job satisfaction; supervision, nature of coaching, sport club's tactics, colleagues, salary, coaching conditions, athletes' performance, social dimension of coaching and professional development. Football coaches had the higher level of satisfaction in all dimensions, whereas coaches of rhythmic gymnastics, athletics, rowing and swimming had the lowest level of satisfaction in most of the dimensions. Comparing team and individual sport coaches it was found that coaches of team sports had significantly higher level of satisfaction in six out of the nine dimensions.

Using the same scale (CSS), Salonikidis, Drakou and Koukouris (2007) explored the role that gender, age and coaching experience play in job satisfaction of tennis coaches. Overall, it was found that coaches were satisfied with job nature, job social dimension and colleagues, moderately satisfied with their supervisors, athletes' performance and salary and less satisfied with their clubs' policies and the training conditions. No differences were found between male and female coaches. However, coaches with many years of coaching experience were significantly less satisfied with their supervisor than coaches with less experience.

More recently, Mokoena and Dhurup (2019) explored the relationships among self-efficacy, organizational commitment, job satisfaction and satisfaction with life, using a sample of amateur sport coaches in South Africa. The results of the study indicated that there were significant positive relationships between organizational commitment and job satisfaction, self-efficacy and organizational commitment, organizational commitment and satisfaction with life and self-efficacy with satisfaction with life.

Accordingly, Chelladurai and Ogasawara (2003) studied both job satisfaction and commitment of American and Japanese Collegiate Coaches. The results showed that there were significant differences between the two nationalities. Japanese were significantly less satisfied than Americans regarding seven dimensions of job satisfaction. Regarding commitment, Americans were found to be more committed to their occupation, whereas Japanese were more committed to their sport organizations.

Turner and Chelladurai (2005) explored organizational and occupational commitment, job satisfaction, withdrawal behaviors and performance in head coaches at NCAA Division I and III institutions. Intercollegiate athletic coaches had the highest scores for affective commitment, both organizational and occupational. They had the lowest scores for continuance commitment, both organizational and occupational again. Regarding differences between organizational commitment and occupational commitment, coaches were found to be higher in commitment to their occupation, only in the affective dimension of commitment.

Moreover, Takamatsu and Yamaguchi (2018) studying the effect of coaching behaviors on job satisfaction and organizational commitment in comprehensive community sport clubs in Japan, found that job satisfaction positively impacted organizational commitment. They went on to conclud that autonomy and the existence of a communication friendly space are necessary pre-requisites to increase coaches' job satisfaction and organizational commitment.

The employment status (full time / part time) is a topic which received much research interest in various jobs such as salesmen (Jackofsky \& Peters, 1987; Karatuna \& Basol, 2017), college instructors (Liu \& Zhang, 2015), employees in the financial services industry (Clinebell \& Clinebell, 2007) and hospital employees (Eberhardt \& Shani, 1984), providing however conflicting results. In some cases, part time employees were found to be more satisfied in overall job satisfaction than full time employees (Eberhardt \& Shani, 1984; Jackofsky \& Peters, 1987), while other studies ended up with the opposite result (Barling \& Gallagher, 1996; Feldman, 1990). Barling and Gallagher (1996) stated that although overall job satisfaction is often equal between full-time and part-time employees, part time employees may be more satisfied with social aspects of the job, such as colleagues and supervision and moreover, they may be less satisfied with rewards. 
Regarding sport environment, Robbinson, Peterson, Tedrick, and Carpenter (2003), in their study of NCAA Division III sport administrators, found that full time administrators were more satisfied. In her study in four-year institutions in California, Snyder (1990) found no differences between full time and part time sport coaches in job satisfaction facets. It is true that the number of people working part time is constantly increasing and changing the working landscape we knew until now (EU Labour Force Survey, 2018). Due to this fact and together with the increase of insecurity at work which is originated by the current economic dynamic, it was expected to find differences in the levels of job satisfaction between full-time and parttime coaches, especially in the dimensions of job security and pay.

The present study attempts to explore the possible differences in job satisfaction dimensions and commitments among coaches of the three major racket sports in Greece (tennis, table-tennis and badminton). Moreover, coaches' employment status (full-time/parttime) was investigated, since it has not been studied thoroughly in the Greek sport environment and not studied at all in the Greek racket sport environment. As a final point, the associations between the dimensions of job satisfaction and commitments will be explored. The interpretation of possible specific relations between these variables could help human resource management in sport clubs to create policies that would lead their employees to higher levels of these concepts. Regarding these, Llobet's and Fito's (2013) perception was adopted which suggests that job satisfaction and commitments cooperate in obtaining high correlations in cross sectional models. Thus, positive correlations are expected to be found among certain dimensions of job satisfaction, organizational commitment and occupational commitment, which could be valuable to all those who determine the human resource policies and practices in Greek racket sport organizations.

\section{METHOD}

\section{Participants}

A total of 110 individuals ( $N=110,82$ : male, 28: female) with a mean age of 33.43 (SD: \pm 9.01 ) years and with 8.44 $(S D: \pm 6.16)$ years of coaching experience, participated in the study. There were 61 participants (55.5\%) who were tennis coaches, 31 (28.2\%) who were table-tennis coaches and 18 (16.4\%) who were badminton coaches. Coaching was the only employment for 46 (41.8\%) of them while $64(58.2 \%)$ had another job at the same time.

\section{Data collection}

Data were collected through anonymous paperpencil questionnaires during national level games. All participants were ensured that their answers will be confidential and that they will be used only for the purpose of the present study.

\section{Measures}

Job Satisfaction. Thirty nine items of the Coach Satisfaction Questionnaire, (CSQ, Chelladurai \& Ogasawara, 2003) were used to assess coaches' job satisfaction. The original questionnaire is an elevenfactor instrument which is composed of 41 items and was designed to measure job satisfaction of coaches in American and Japanese universities. Five items of the original questionnaire which refer to 'athletes' academic performance' and to 'media and community' support were excluded. The exclusion of these items was decided because it was judged that they did not fit to the Greek national organizational structure of racket sports. In particular, unlike US and Japanese collegiate sports, in Greece there is no connection of tennis, table-tennis and badminton teams with education performance or media's financial support. The remaining 36 items of the questionnaire referred to 'autonomy' (6 items), 'coaching job' (7 items), 'team performance' (5 items), 'supervision' (5 items), 'facilities' (3 items), 'pay' (2 items), 'amount of work' (3 items), 'colleagues' (3 items) and 'job security' (2 items). The Greek version of the instrument has been successfully used in a previous study (Georgiadi, 2008), giving evidence of adequate validity and reliability. The responders were asked to specify the extent of their satisfaction with the statement of each item using a 9-point Likert scale (1 = not at all, 9 = very much).

Occupational and organizational commitment. The Occupational-Organizational Commitment Scale (Meyer, Allen, \& Smith, 1993) was used to evaluate participants' occupational and organizational commitment. It consists of two scales of 18 items each, occupational commitment scale and organizational commitment scale, which both in turn consist respectively of three sub-scales referring to three different forms of commitment: affective ( 6 items), continuance ( 6 items) and normative (6 items) commitment. This questionnaire has been also used in Greek language showing acceptable validity and reliability (Georgiadi, 2008). Participants were asked to indicate the extent of their agreement with the statement of each item using a 7-point Likert scale (1 = strongly disagree, 7 = strongly agree).

Mean scale scores were computed for every subscale of the questionnaires. Hence, nine new variables were created (autonomy, coaching job, team performance, supervision, pay, facilities, amount of work, colleagues and job security) for the Coach Satisfaction Questionnaire and six (occupational affective commitment, occupational normative commitment, occupational continuance commitment, organizational affective commitment, organizational normative commitment and organizational continuance commitment) for the OccupationalOrganizational Commitment Scale. 


\section{Statistical analysis}

Cronbach's alpha coefficient was used to assess the internal consistency of the instruments and Pearson's $r$ index to explore the correlations between the variables which were created. For the investigation of possible differences between full time and part time coaches and between tennis, table tennis and badminton coaches, a series of independent samples' $t$-tests and one-way ANOVAs were used. The posthoc test of Scheffe with a $95 \%$ confidence interval was used for the examination of possible differences between coaches of different racket sports. Cohen's $d$ and partial eta squared coefficients were used for the evaluation of the strength of the differences that were found.

A series of multiple regression analyses with the 'stepwise' method was used for the further investigation of the association between 'commitment' and 'job satisfaction' variables. In each analysis one of the 'commitment' variables served as the depended variable and all the 'job satisfaction' variables as predictors. With the 'stepwise' method, the statistical package determines and enters in the model the subset of the most useful predictors excluding these which do not contribute to the prediction of the depended variable. To ensure that there was not any multicollinearity between the predictors, the Variance Inflation Factor (VIF) was calculated. VIF values close to 1 indicate that there are not multicollinearity effects on the model (Field, 2009, p. 224).

\section{RESULTS}

Full time coaches scored higher in scales assessing 'supervision', 'team performance', 'facilities', 'pay', 'amount of work' and 'job security'. Several differences were found between coaches of different racket sports and more precisely in 'autonomy', 'coaching job', 'supervision', 'pay', amount of work', 'colleagues', 'job security' and 'occupational affective commitment' (Tables 1a \& 1b).

Table 2 presents the internal consistency indices of the scales. All alpha values were close or over .70 (Cronbach, 1951) giving evidence of satisfactory internal consistency of the questionnaires and were as expected. Almost all 'job satisfaction' variables were highly correlated. The highest significant correlation $(r=.66)$ was noticed between 'autonomy' and 'coaching job' whereas the lowest $(r=.26)$ between 'coaching job' and 'amount of work'. Various correlations were noticed between the commitment variables. The highest significant correlation was noticed between 'organizational affective commitment' and 'organizational normative commitment' $(r=.59)$ while the lowest between 'occupational continuance commitment' and 'organizational affective commitment' $(r=.20)$. The highest significant correlation between the 'job satisfaction' and 'commitment' variables was noticed between 'supervision' and 'organizational affective commitment' ( $r=.40)$ whereas the lowest between 'job security' and 'organizational continuance commitment' $(r=.20)$.

The most significant predictors of the three 'occupational commitment' variables were 'job satisfaction' and 'team performance'. 'Job satisfaction' was the only independent variable that was entered into the prediction model of 'occupational affective and normative commitment' whereas 'team performance' was the only that was entered into the prediction model of 'occupational continuance commitment'. With regard to 'organizational commitment' variables, 'supervision' and 'autonomy' were the predictors of 'organizational affective commitment' and 'colleagues' and 'coaching job' were the predictors of 'organizational normative commitment'. Not one of the 'job satisfaction' variables was entered in the prediction model of 'organizational continuance commitment' (Table 3).

Table 1a.

Mean differences in all variables between full time and part time coaches

\begin{tabular}{lccccccc}
\hline & \multicolumn{1}{c}{ Full-time } & \multicolumn{2}{c}{ Part-time } & & & \\
& $M$ & $S D$ & $M$ & $S D$ & $t$ & Sig. & $d$ \\
\hline Job Satisfaction & & & & & & & \\
Autonomy & 7.81 & .90 & 7.78 & .92 & .21 & .833 & .04 \\
Coaching job & 7.67 & .88 & 7.33 & 1.05 & 1.79 & .076 & .35 \\
Team performance & 7.44 & .81 & 7.01 & 1.09 & 2.19 & .031 & .44 \\
Supervision & 6.86 & 1.49 & 5.92 & 1.62 & 3.03 & .003 & .60 \\
Facilities & 6.23 & 2.38 & 5.18 & 2.36 & 2.24 & .027 & .44 \\
Pay & 6.40 & 1.98 & 5.14 & 2.26 & 3.02 & .003 & .59 \\
Amount of work & 6.08 & 1.61 & 5.19 & 1.42 & 3.04 & .003 & .59 \\
Colleagues & 7.68 & 1.57 & 7.09 & 1.56 & 1.87 & .064 & .38 \\
Job security & 6.34 & 2.01 & 5.19 & 1.90 & 3.05 & .003 & .59 \\
$\begin{array}{l}\text { Occupational } \\
\text { Affective }\end{array}$ & & & & & & & \\
commitment & 5.13 & .67 & 5.08 & .62 & .39 & .695 & .08 \\
$\begin{array}{l}\text { Continuance } \\
\text { commitment }\end{array}$ & 4.65 & 1.20 & 4.32 & 1.19 & 1.35 & .181 & .28 \\
$\begin{array}{l}\text { Normative } \\
\text { commitment }\end{array}$ & 4.63 & 1.04 & 4.54 & .96 & .45 & .650 & .09 \\
$\begin{array}{l}\text { Organizational } \\
\text { Affective }\end{array}$ & & & & & & & \\
commitment & 4.59 & .99 & 4.45 & 1.00 & .67 & .499 & .13 \\
$\begin{array}{l}\text { Continuance } \\
\text { commitment }\end{array}$ & 4.38 & 1.02 & 4.10 & 1.15 & 1.28 & .200 & .26 \\
$\begin{array}{l}\text { Normative } \\
\text { commitment }\end{array}$ & 4.93 & 1.01 & 4.36 & 1.02 & 2.82 & .006 & .56 \\
\hline & & & & & & & \\
\hline
\end{tabular}


Table $1 \mathrm{~b}$.

Mean differences in all variables between coaches of different racket sport

\begin{tabular}{|c|c|c|c|c|c|c|c|c|c|}
\hline & \multicolumn{2}{|c|}{ Tennis } & \multicolumn{2}{|c|}{ Table-tennis } & \multicolumn{2}{|c|}{ Badminton } & \multirow[b]{2}{*}{$F$} & \multirow[b]{2}{*}{ Sig. } & \multirow[b]{2}{*}{$\eta_{p}^{2}$} \\
\hline & M & $S D$ & $M$ & $S D$ & $M$ & $S D$ & & & \\
\hline \multicolumn{10}{|l|}{ Job Satisfaction } \\
\hline Autonomy & 7.75 & .95 & 8.12 & .87 & 7.32 & .55 & $4.504 c$ & .013 & .082 \\
\hline Coaching job & 7.66 & .95 & 7.40 & 1.12 & 6.97 & .61 & $3.514_{b}$ & .033 & .079 \\
\hline Team performance & 7.19 & 1.03 & 7.31 & .94 & 6.92 & 1.04 & .794 & .455 & .015 \\
\hline Supervision & 6.68 & 1.54 & 6.09 & 1.83 & 5.54 & 1.23 & $3.852_{b}$ & .024 & .070 \\
\hline Facilities & 5.83 & 2.35 & 5.67 & 2.58 & 4.90 & 2.29 & .982 & .378 & .018 \\
\hline Pay & 6.61 & 1.68 & 4.46 & 2.40 & 4.61 & 2.13 & $15.061_{a, b}$ & .000 & .221 \\
\hline Amount of work & 6.03 & 1.31 & 4.94 & 1.84 & 5.12 & 1.34 & $6.418_{a}$ & .002 & .108 \\
\hline Colleagues & 7.87 & 1.17 & 7.06 & 1.78 & 5.84 & 1.51 & $12.632_{\mathrm{a}, \mathrm{b}, \mathrm{c}}$ & .000 & .201 \\
\hline Job security & 6.22 & 1.78 & 5.19 & 2.41 & 4.69 & 1.52 & 5.620 & .005 & .095 \\
\hline \multicolumn{10}{|l|}{ Occupational } \\
\hline Affective commitment & 5.25 & .65 & 4.94 & .65 & 4.88 & .47 & 3.587 & .051 & .066 \\
\hline Continuance commitment & 4.55 & 1.10 & 4.05 & 1.35 & 4.95 & 1.03 & 3.002 & .054 & .058 \\
\hline Normative commitment & 4.65 & .98 & 4.54 & 1.10 & 4.39 & .82 & .435 & .648 & .008 \\
\hline \multicolumn{10}{|l|}{ Organizational } \\
\hline Affective commitment & 4.51 & 1.10 & 4.71 & .85 & 4.20 & .76 & 1.475 & .234 & .027 \\
\hline Continuance commitment & 4.11 & 1.18 & 4.51 & .85 & 4.03 & 1.22 & 1.559 & .215 & .029 \\
\hline Normative commitment & 4.65 & 1.14 & 4.79 & .91 & 4.02 & .68 & 2.816 & .065 & .052 \\
\hline
\end{tabular}

Note: $\mathrm{a}=$ statistical differences between tennis and table-tennis coaches $(p<.05), \mathrm{b}=$ statistical differences between tennis and badminton coaches $(p<.05), c=$ statistical differences between table-tennis and badminton coaches $(p<.05)$

Table 2.

Correlations between all the depended variables and Conbach's a of the scales in the diagonal

\begin{tabular}{|c|c|c|c|c|c|c|c|c|c|c|c|c|c|c|c|}
\hline & 1 & 2 & 3 & 4 & 5 & 6 & 7 & 8 & 9 & 10 & 11 & 12 & 13 & 14 & 15 \\
\hline Autonomy & .68 & & & & & & & & & & & & & & \\
\hline Coaching job & $.66^{\star *}$ & .77 & & & & & & & & & & & & & \\
\hline Team performance & $.54^{\star *}$ & $.45^{\star *}$ & .70 & & & & & & & & & & & & \\
\hline Supervision & $.38^{* *}$ & $.52^{\star *}$ & $.48^{* *}$ & .85 & & & & & & & & & & & \\
\hline Facilities & $.31^{* *}$ & $.32^{* *}$ & $.62^{\star \star}$ & $.47^{* *}$ & .91 & & & & & & & & & & \\
\hline Pay & .15 & $.33^{* *}$ & $.31^{* *}$ & $.47^{* \star}$ & $.51^{* *}$ & .77 & & & & & & & & & \\
\hline Amount of work & .16 & $.26 * *$ & $.31^{\star *}$ & $.44^{\star *}$ & $.32^{* *}$ & $.44^{* *}$ & .68 & & & & & & & & \\
\hline Colleagues & $.27^{\star *}$ & $.35^{* *}$ & $.41^{* *}$ & $.53^{* *}$ & $.30 * *$ & $.46^{* *}$ & $.38^{* *}$ & .86 & & & & & & & \\
\hline Job security & .15 & $.41^{* *}$ & $.33^{* *}$ & $.42^{\star *}$ & $.43^{* *}$ & $.61^{* *}$ & $.49^{* *}$ & $.42^{* *}$ & .76 & & & & & & \\
\hline Occ. affective commitment & $.25^{*}$ & $.33^{* *}$ & .12 & .12 & .03 & .17 & .09 & .11 & .17 & .67 & & & & & \\
\hline Occ. continuance commitment & .19 & $.22^{*}$ & $.40^{* *}$ & .19 & $.29 * *$ & .18 & .15 & .14 & .19 & .15 & .72 & & & & \\
\hline Occ. normative commitment & $.25^{*}$ & $.37^{* *}$ & $.26^{\star *}$ & $.24^{*}$ & $.24^{*}$ & $.23^{*}$ & .07 & -.01 & $.21^{*}$ & $.42 * *$ & $.29 * *$ & .70 & & & \\
\hline Org. affective commitment & $.39 * *$ & $.38^{* *}$ & $.26^{* *}$ & $.44^{* *}$ & .19 & .18 & .05 & $.32^{*}$ & .11 & $.21^{*}$ & $.20^{*}$ & $.48^{* *}$ & .78 & & \\
\hline Org. continuance commitment & -.01 & .08 & .06 & .13 & .13 & .09 & -.02 & .13 & $.20^{*}$ & -.16 & .12 & -.02 & $.29 * *$ & .73 & \\
\hline Org. normative commitment & $.24^{*}$ & $.37^{* *}$ & .16 & $.34^{* *}$ & .11 & $.20 *$ & .06 & $.33^{* *}$ & .19 & .06 & .11 & $.37^{\star \star}$ & $.59 * *$ & $.43^{* *}$ & .72 \\
\hline
\end{tabular}

Note: ${ }^{*}=p<.05, * *=p<.001$ 
Table 3.

Stepwise regression analyses of commitment variables

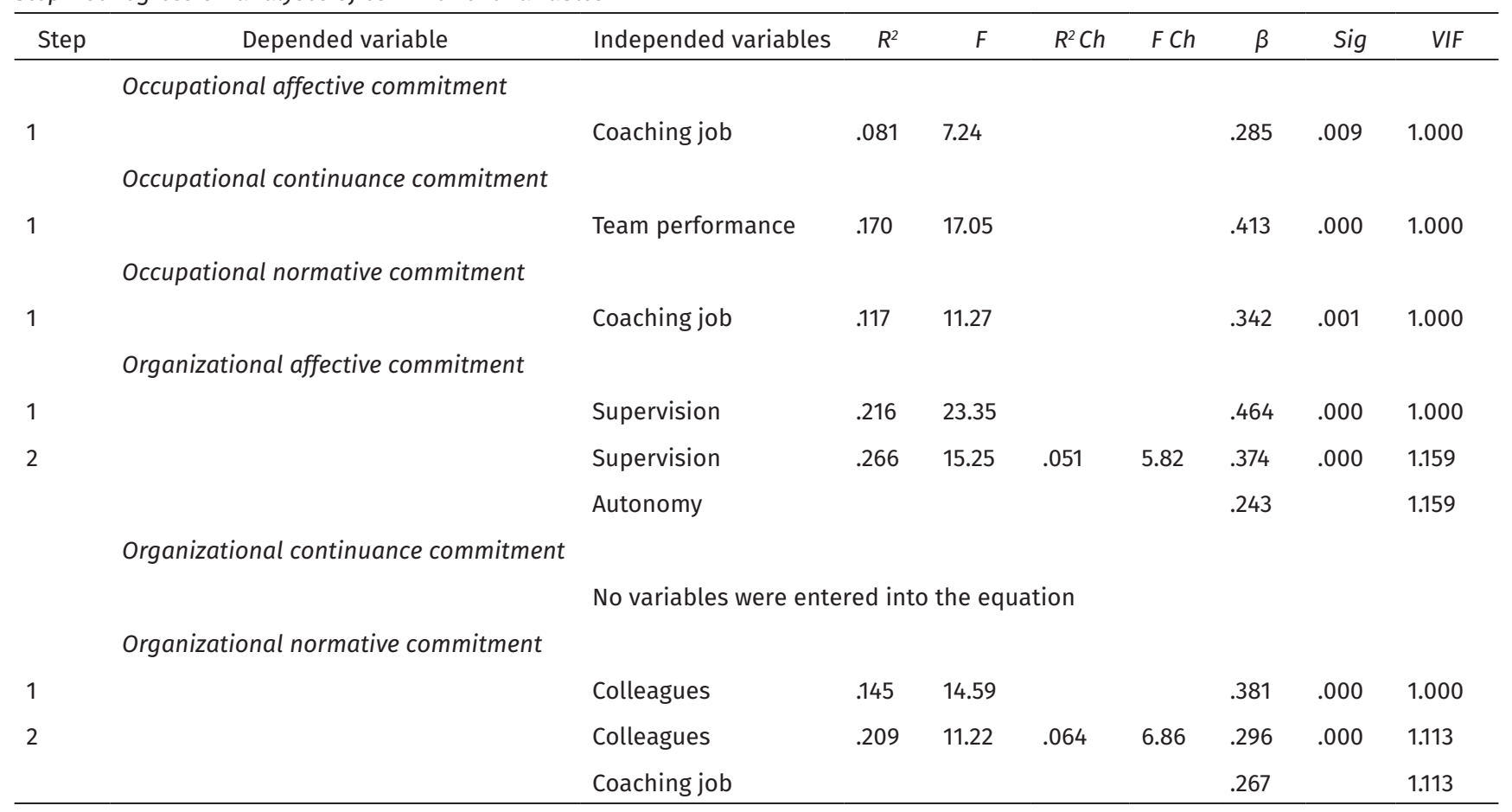

\section{DISCUSSION}

Sport coaching is a very demanding profession since it requires technical and tactical knowledge of sport, deep understanding of human movement, managing highly stressed situations, and inspiring people to get the best out of them. People who chose this occupation need to be multi skilled to cope with all these various demands. Sport clubs, on the other hand, seek coaches with the skills above, coaches who strongly believe in the values of coaching and desire to build a career on it (high occupational commitment) and, at the same time, coaches who strongly desire to participate in all club's activities, putting as much effort as they can (high organizational commitment). It is a real asset for sport clubs to have that kind of coaches. As Chelladurai (1999) mentions, total commitment contributes in organizational success and practitioners ought to understand and use this information since success is the key point for every sport organization. Hence, ideally, sport administration uses managerial tools in order to create a motivating environment that could enforce job satisfaction and commitment, such as training, reward system and satisfying working conditions.

To begin with, the presentstudy explored differences in coaches' job satisfaction and in occupational and organizational commitment due to different sport (tennis, table-tennis, badminton) and due to different occupational status (full-time, part-time).

Regarding different sports, various differences were revealed in job satisfaction among coaches from different sports, which could be concluded in that tennis coaches scored higher level of satisfaction with five out of the nine dimensions (autonomy, supervision, pay, colleagues, and job security). Badminton coaches seem to be less satisfied than tennis coaches and in some occasions than tennis table coaches too. A possible explanation might be that tennis is more popular in Greece than the other two racket sports. It involves sponsorships, media interest, and lately world distinguished athletes. Additionally, tennis coaching is an extra service offered in many Greek hotels, villas and resorts. The larger number of alternatives that a tennis coach has in order to find a job, compared to the alternatives of tennis table and badminton coaches, may increase the probability to find a job that will satisfy him/her more. As to the working status, according to Llobet and Fito (2013) many conditions have changed globally in working environments (number of occupations at the same time per person, part time occupation, working from home, using new technology) and these may have an effect on job satisfaction. What used to satisfy an employee of the 20th century may differ from what satisfies an employee of 2020. Things change and this happens faster than ever. That is why studying job satisfaction and commitment remains always among the interests of the scientific community. In Greece, it is very common for a coach to have more than one occupation and the results of this study come to confirm this. More than two out of every five coaches have only one occupation. That is, a large percentage of sport coaches have more than one job at the same time. This is in accordance with Eurostat data which show that there is a continuous increase in the number of people working part time (EU Labour Force 
Survey, 2018); in 2005, the percentage of part time employees in EU were $15.6 \%$ of total employment, whereas in 2018, this percentage has been increased to $17.8 \%$. According to this study's results, and as it was expected, full time coaches are significantly more satisfied than part time coaches, with five out of the nine job satisfaction dimensions. More precisely, they are more satisfied with team performance, supervision, facilities, pay and amount of work. Robinson and his colleagues (2003) came to the same conclusion in their study in sport environment, revealing that sport full time administrators were more satisfied with their job than their part time colleagues. However, as it was mentioned in the introduction, results are conflicting (Eberhardt \& Shani, 1984; Jackofsky \& Peters, 1987; Snyder, 1990).

With respect to the correlations among job satisfaction dimensions, this study, as it was expected, came to prove the strong correlation between "autonomy" and "coaching itself". Autonomy is in the nature of coaching, it is a prerequisite for a coach to train, lead, inspire. This result is in line with Takamatsu's and Yamaguchi's (2018) results in a similar study, where they argue that autonomy is a necessary precondition for increasing coaches' job satisfaction and organizational commitment. Additionally, the results of this study showed the lowest correlation among job satisfaction dimensions between 'coaching job' and 'amount of work'. This comes as no surprise, if one recalls what training is all about; countless repetitions until perfect technique is achieved, late hours training, weekend competition obligations.

Regarding occupational commitment, the results, as shown by the means (Table 1) demonstrated that coaches had the highest score in occupational affective commitment followed by occupational normative commitment. Regarding organizational affective commitment, coaches had the highest scores in normative commitment followed by affective. Continuance commitment, both organizational and occupational, had the lowest scores, which is in accordance with Turner's (2001) study about head coaches at NCAA.

Concerning correlations between organizational and occupational commitments, the results, as shown in table 2, depicted various correlations among the six dimensions, with the highest significant one to be noticed between 'organizational affective commitment' and 'organizational normative commitment'. In other words, coaches with high emotional attachment and identification to their club are more likely to feel obliged to remain to that specific club. Furthermore, from highest to lowest, the correlations below also emerged; organizational affective commitment was significantly correlated: a) to occupational affective commitment, a result that is in accordance with Yousaf' $s$ and colleagues' result in a similar study (2015), b) to occupational normative commitment, and c) to occupational continuance commitment. As
Watson and Clark (1997) state, organizational affective commitment represents an employee's positive emotional reaction to the organization. This means that coaches emotionally attached to their club, have positive reactions towards the club and regarding the results of this study they also feel obliged to continue their careers in the profession of coaching. Additionally, regarding the results of this study, they love coaching and have invested time and effort to it, so they do not intent to leave the profession. In parallel, it is in the advance of club administration to seek ways to capture and cultivate organizational attachment of its coaches. If one takes for granted that clubs also invest on their coaching personnel, it should be of their high priority to keep them in their force.

On the topic of "job satisfaction - organizational commitment" relationship, the results of this study are consistent with previous ones (Ahmad, Ahmad \& Shah, 2010; Mokoena \& Dhurup, 2019; Suma \& Lesha, 2013) suggesting that there is a significant relationship between the two concepts. More precisely, "supervision" and organizational affective commitment correlate to each other with the highest score and consequently it was the most important predictor of this dimension. This could be interpreted in that if a coach is satisfied with the way supervision upon his/her job is performed, then s/he is more likely to show affiliative behaviors towards his/her club. Supervision is performed by people (head coach, owner of the club, technical advisor of the sport federation in the case a national coach, etc.). It is therefore included in the social aspects of coaching together with colleagues (Spector, 1997). It seems that social or human relations are the ones that could create affiliation and emotional attachment to the employee towards the organization. In the same manner, Takamatsu and Yamaguchi (2018) mentioned that a working environment where communication with many people is welcomed and encouraged, plays important role in increasing coaches' job satisfaction and organizational commitment. Supervision also was found to correlate to organizational normative and occupational normative commitments, in a way that proper supervision can "create" an informal, psychological contract that "obliges" a coach to remain in the club and in the profession respectively. In line with other studies (Suma \& Lesha, 2013) supervision is an important facet of job satisfaction regarding its correlation to commitments.

Regarding the dimension of autonomy, it was found that besides being a predictor of the organizational affective commitment, it also correlates to organizational normative commitment to occupational affective and occupational normative commitment. This is very important information for sport administrators who aim to keep their personnel. It could be used in job design and in policy planning. Giving space to coaches seems to be a component of 
the informal, psychological contract mentioned in the previous paragraph that will keep them in the sport club.

As it was expected, satisfaction with coaching job was correlated to all occupational commitment dimensions. Moreover it was the unique predictor of occupational affective and occupational normative commitment and it was also a predictor of organizational normative commitment. It is straightforward that coaches who are satisfied with the nature of coaching, have feelings of affiliation for it, have invested a lot and do not intend to quit. Moreover, regarding organizational commitment, it was found that they were identified to their club and they felt obliged to keep working there, result which is in accordance with Suma's \& Lesha's (2013) study upon employees of public sector. The authors above found that satisfaction with work-itself had significant positive influence on organizational commitment of municipality employees.

According to the findings, team performance was correlated to organizational affective commitment, occupational normative commitment and occupational continuance commitment. Additionally from the regression analysis results it was found to be the only predictor of occupational continuance commitment. In other words, coaches who are satisfied with their team or athletes' performance, are emotionally connected to their club, they believe it would cost them to work at another club, since they have invested a lot and are satisfied with the results of their investment. Additionally, they feel obliged to continue in coaching career.

Facilities, were correlated with all the job satisfaction variables and with two of the three occupational commitment dimensions; continuance and normative. In other words, coaches who are satisfied with sport facilities (gym halls, equipment, training conditions) are committed to their job in a way that they feel they have to stay in their coaching career, they owe it to the sport, and changing career would cost them a lot in terms of money, time and effort.

Moreover, this study revealed that pay satisfaction was correlated to normative commitment, both organizational and occupational. This is in line with Vandenbeghere' result in a similar study (2008), and partially in accordance with Turner's study (2001) which showed that pay satisfaction correlates to all the three dimensions of organizational commitment. Nevertheless, it is opposite to the result in Suma's and Lesha's (2013) study, where no correlation between pay satisfaction and commitment was found. However, and regarding this study, money seems to create feelings of obligation; it is in its exchange nature. Coaches of this study were moderately satisfied with their salary, but it seems that even this level of satisfaction keeps them in job and their club, because of feelings of obligation.
Interestingly, there was no correlation between "amount of work" and organizational and occupational dimensions, when explored one by one. As mentioned at the beginning of the discussion, coaching includes a large amount of work, not only considering training hours, but also hours spent in meetings with administrators, parents, athletes, studying and planning at home. Regarding the results, it seems that sport coaches' commitment to both club and occupation is not influenced by hard working. This result comes to reinforce the result of Robinson's and his colleagues' (2003) study for athletic directors, which proved that the amount of time spent on job duties, is not a predictor of job satisfaction.

\section{CONCLUSIONS}

Many researchers agree that the relationship with colleagues is one of the major sources of job satisfaction (Drakou, 2006; Rintaugu, 2013; Takamatsu \& Yamaguchi, 2018). Regarding this study satisfaction with the relationship with colleagues was among the three highly scored dimensions together with satisfaction with autonomy and coaching itself. The dimension "colleagues" was also found to correlate to organizational affective and organizational normative commitment and according to the regression analysis results it was the most significant predictor of organizational normative commitment. In other words, maybe it is not always important for a club to have the best coaches, but instead it is rather more important to have coaches who enjoy working together. This climate of cooperation can create stronger ties between coaches and sport organization, and that may lead to long-term, successful partnership (Bakotić, 2016; Nilipour Tabatabei, Takapoo, \& Leilaeyoun, 2015; Wright, Gardner, Moynihan, \& Allen, 2005).

Finally, satisfaction with job security was found to correlate to organizational continuance commitment. This is the only case in the study, where a job satisfaction dimension correlates to continuance commitment. It is straightforward that coaches estimate the costs associated with leaving their club, and their final decision to remain or leave is taken considering what they lose. Job security seems to be a critical factor in this decision.

\section{Limitations}

The causal order of job satisfaction and commitments was not of the interest of this paper and this may be considered a limitation of this research. Given the fact that past results did not show any consistency (Llobet \& Fito, 2013) this certainly needs to be further explored.

\section{Suggestions}

Further research needs to be conducted on the human relation practices of the National Federations 
and/or sport clubs associated with them, in order to have a better understanding of how certain practices and policies lead to higher levels of job satisfaction, organizational and occupational commitment among racket sport coaches. Moreover, while research on employment status and job satisfaction has led to contradictory results so far, future research should focus not only on the employment status (full time / part time) but also on the amount of hours spending on coaching in relation with employment status.

\section{REFERENCES}

Abuhashesh, M., Al-Dmour, R. \& Masa'deh, R. (2019). Factors that affect employees' job satisfaction and performance to increase customers' satisfactions. Journal of Human Resources Management Research, 1-23. DOI: $10.5171 / 2019.354277$

Ahmad, H., Ahmad, K., \& Shah, I. A. (2010). Relationship between job satisfaction, job performance attitude towards work and organizational commitment. European Journal of Social Sciences, 18(2), 257-267.

Bakotić, D (2016). Relationship between job satisfaction and organizational performance. Economic Research-Ekonomska Istraživanja, 29(1), 118-130.

Barling, J., \& Gallagher, D. G. (1996). Part-time employment. In C. L. Cooper \& I. T. Robertson (Ed.), International review of industrial and organizational psychology (Vol. 11, pp. 243- 277). Chichester: Wiley.

Barnhill, C. R., Martinez, J. M. Andrew, D. P., \& Todd, W. (2018). Sport commitment, occupational commitment, and intent to quit among high school sport officials. Journal of Amateur Sport, 4(1), 1-21.

Bateman, T. S., \& Strasser, S. (1984). A longitudinal analysis of the antecedents of organizational commitment. Academy of Management Journal, 27, 95-112.

Bradford Conant, E. (2017). The impact of role conflict on job satisfaction of independent school athletic directors. Journal of Amateur Sport, 3(1), 1-26.

Chelladurai, P. (1999). Human resource management in sport and recreation. Champaign, IL: Human Kinetics.

Chelladurai, P., \& Ogasawara, E. (2003). Satisfaction and commitment of American and Japanese collegiate coaches. Journal of Sport Management, 17(1), 62-73.

Clinebell, S. K., \& Clinebell, J. M. (2007). Differences between part-time and full-time employees in the financial services industry. Journal of Leadership \& Organizational Studies, 14(2), 157-167.

Courtney, C., \& Younkyoung, K. (2017). Intentions to turnover. Leadership and Organizational Development Journal, 38(2), 194-209.

Cronbach, L. (1951). Coefficient alpha and the internal structure of test. Psychometrika, 16, 297-334.
Currivan, D. B. (1999). The casual order of job satisfaction and organizational commitment in models of employee turnover. Human Resource Management Review, 9(4), 495-524.

Drakou, A. (2006). Job satisfaction among sport coaches in Greece. (Unpublished doctoral dissertation). Democritus University of Thrace, Komotini, Greece.

Drakou, A., Charachousou, Y., Kambitsis, N. \& Tzetzis, G. (2008). Job satisfaction differences among coaches of various sports in Greece. Inquiries in Sport and Physical Education, 6(1), 97-110.

Drakou, A., Kambitsis, C., Charachousou, Y., \& Tzetzis, G. (2006). Exploring life satisfaction of sport coaches in Greece. European Sport Management Quarterly, 6(30), 239-252.

Eberhardt, B. J., \& Shani, A. B. (1984). The effect of full-time versus part-time employment status on attitudes toward specific organizational characteristics and overall job satisfaction. Academy of Management Journal, 27, 893-900.

Erdheim, J., Wang, M., \& Zickar, M. J. (2006). Linking the Big Five personality constructs to organizational commitment. Personality and Individual Differences, 41, 959-970.

European Union Labour Force Survey (2018). Retrieved on 22 April 2020 by https://ec.europa.eu/eurostat/ web/microdata (European Statistics).

Feldman, D. C. (1990). Reconceptualizing the nature and consequences of part time work. Academy of Management Review, 15, 103-112.

Field, A. (2009). Discovering statistics using IBM SPSS (3rd eds.). London, UK: Sage.

Fiúekçioglu, B., \& Savaú Duman, S. (2010). An investigation of job satisfaction levels of sports managers working in amateur sports clubs. Procedia Social and Behavioral Sciences, 2, 4901-4905.

Georgiadi, O. (2008). Coaches' job satisfaction and commitment. (Unpublished master's thesis). University of Thessaly, Trikala, Greece.

Gillet, B., \& Schwab, D. P. (1975). Convergent and discriminant validities of corresponding Job Discriptive Index and Minnesota Satisfaction Questionnaire scales. Journal of Applied Psychology, $60,313-317$.

Grobler, S., \& Govender, L. (2017). Job satisfaction and organizational commitment in a South African airline. African Journal of Hospitality, Tourismand Leisure. 6(2), 1-24.

Herzberg, F., Mausner, B., \& Snyderman, B. (1959). The motivation to work. New York: John Wiley.

Hoseong, J. \& Beomjoon, C. (2012). The relationship between employee satisfaction and customer satisfaction. Journal of Services Marketing, 26(5), 332-341. 
Iverson, R. D. (1992). Employee intent to stay: An empirical test of a revision of thePrice and Mueller model. (Unpublisheddoctoral dissertation). The University of Iowa, lowa City, US.

Jackofsky, E. F., \& Peters, L. H. (1987). Part time versus full time employment status differences: a replication and extension. Journal of Organizational Behavior, 8, 1-9.

Karatuna, I., \& Basol, O. (2017). Job satisfaction of parttime vs full-time workers in Turkey: The effect of income and work status satisfaction. International Journal of Value Chain Management, 8(1), 58-72.

Lance, C. E. (1991). Evaluation of a structural model relatingjobsatisfaction,organizationalcommitment, and precursors to voluntary turnover. Multivariate Behavioral Research, 26, 137-162.

Lee, K., Carswell, J. \& Allen, N. (2000). A meta-analytic review of occupational commitment: Relations with person and work - related variables. Journal of Applied Psychology, 85(5), 799-811.

Lincoln, J. R., \& Kalleberg, A. L. (1990). Culture, control and commitment: A study of work organization and work orientations in the United States and Japan. Cambridge: Cambridge University Press.

Liu, X., \& Zhang, L. (2015). Examining the relationship among part-time work arrangements, job satisfaction, and work effort: a study of U.S. college faculty. Advances in Industrial and Labor Relations, 21, 87-117.

Llobet, J., \& Fito, M. A. (2013). Contingent workforce, organizational commitment and job satisfaction: Review, discussion and research agenda. Intangible Capital, 9(4), 1068-1079.

Mathieu, J. E. (1991). A cross-level nonrecursive model of the antecedents of organizational commitment and satisfaction. Journal of Applied Psychology, 76, 607-618.

Meyer, J. P., \& Allen, N. J. (1991). A three-component conceptualization of organizational commitment. Human Resource Management Review, 1, 61-89.

Meyer, J. P., \& Allen, N. J. (1997). Commitment in the Workplace: Theory, Research and Application. Thousand Oaks, California: Sage.

Meyer, J. P., Allen, N. J., \& Smith, C. A. (1993). Commitment to organizations and occupations: Extension and test of a Three-Component conceptualization. Journal of Applied Psychology, 78(4), 538-551.

Mokoena, B., \& Dhurup, M. (2019). Self-efficasy, organizational commitment, job satisfaction, and satisfaction with life relationships: a study among amateur sport coaches in South Africa. International Journal of Social Sciences and Humanity studies, 11(1), 19-34.
Mueller, C. W., Boyer, E. M., Price, J. L., \& Iverson, R. D. (1994). Employee attachment and noncoercive conditions of work: The case of dental hygenists. Work and Occupations, 21, 179-212.

Nath Gangai, K., \& Agrawal, R. (2014). Job satisfaction and organizational commitment: is it important for employee performance? International Journal of Management and Business Research, 5(4), 269-278.

Nilipour Tabatabei, A., Takapoo, F., Leilaeyoun, A. (2015). The Effective of Job Satisfaction on Organizational Citizenship Behavior. International Journal of Academic Research in Business and Social Sciences, 5(1), 155-165.

Podsakoff, N. P., Podsakoff, P. M., \& McKenzie, C. B. (2014). Consequences of uni-level organizational citizenship behaviors: a review and recommendations for further research. Journal of Organizational Behavior, S1, 87-119.

Rintaugu, A. G. (2013). Sources of job satisfaction among sport personnel in Kenyan universities. International Journal of Sports Science, 3(6), 211216.

Robbins, S. P., \& Judge, T. A. (2018). Essential of Organizational Behavior (14th eds). London: Pearson Eds.

Robinson, M. J, Peterson, M., Tedrick, T., \& Carpenter, J. R. (2003). Job satisfaction on NCAA Division III athletic directors. International Sports Journal, 7(2), 46-57.

Salonikidis, K., Drakou, A., \& Koukouris, K. (2007). The influence of gender, age and experience in satisfaction of male and female professional tennis coaches. Hellenic Journal of Sports \& Recreation Management, 4(1), 18-35.

Satoh, M., Watanabe, I., \& Asakura, K. (2016). Occupational commitment and job satisfaction mediate effort-reward imbalance and the intention to continue nursing. Japan Journal of Nursing Science, 14(1), 49-60.

Schleicher, D. J., Smith, T. A., Casper, W. J., Watt, J. D., \& Greguras, G. J. (2015). It's all in the attitude: the role of job attitude strength in job attitude-outcome relationships. Journal of Applied Psychology, 100(4), 1259-1274.

Snape, E., Wing-hung Lo, C., \& Redman, T. (2008). The three-component model of occupational commitment: a comparative study of Chinese and British accountants. Journal of cross cultural psychology, 39(6), 765-781.

Snyder, C. J. (1990). The effects of leader behavior and organizational climate on intercollegiate coaches' job satisfaction. Journal of Sport Management, 4(1), 59-70. 
Spector, P. E. (1997). Job satisfaction - Application, Assessment, Couses, and Consequences. Thousand Oaks, California: SAGE Publications.

Srivastava, S. (2013). Job Satisfaction and Organizational Commitment Relationship: Effect of Personality Variables. Vision: The journal of Business Perspective, 17(2), 159-167.

Suma, S., \& Lesha, J. (2013). Job satisfaction and organizational commitment: the case of Shkodra Municipality. European Scientific Journal, 9(17), 4151.

Takamatsu, S., \& Yamaguchi, Y. (2018). Effect of coaching behaviors on job satisfaction and organizational commitment: The case of comprehensive community sport clubs in Japan. International Journal of Sports Science \& Coaching, 13(4), 508-519.

Turner, B. A. (2001). Commitment among intercollegiate athletic coaches. (Unpublished doctoral dissertation). School of the Ohio State University, Ohio City, US.

Turner, B. A., \& Chelladurai, P. (2005). Organizational and occupational commitment, intention to leave, and perceived performance of intercollegiate coaches. Journal of Sport Management, 19(2), 193211.

Vandenberg, R. J., \& Lance, C. E. (1992). Examining the causal order of job satisfaction and organizational commitment. Journal of Management, 18, 153-167.
Vandenberghere, C. (2008). The role of pay satisfaction and organizational commitment in turnover intentions: A two-sample study. Journal of Business and Psychology, 22(3), 275-286.

Wallace, J. E. (1995). Corporatist control and organizational commitment among professionals: The case of lawyers working in law firms. Social Forces, 73, 811-840.

Wang, L., Tao, H., Ellenbecker, C. H., \& Liu, X. (2011). Job satisfaction, occupational commitment and intent to stay among Chinese nurses: A cross-sectional questionnaire survey. Journal of Advanced Nursing, 68(3), 539-49.

Watson, D., \& Clark, L. A. (1997). Extraversion and its positive emotional core. In S. R. Briggs, W. H. Jones, \& R. Hogan (Eds.), Handbook of personality psychology. New York: Academic Press.

Wright, P. M., Gardner, T. M., Moynihan, L. M., \& Allen, M. R. (2005). The relationship between HR practices and firm performance: Examining causal order. Personnel Psychology, 58, 409-446.

Yousaf, A., Sanders, K., \& Abbas, Q. (2015). Organizational/occupational commitment and organizational/occupational turnover intentions. Personnel Review, 44(4), 470-491. 